\title{
Effect of dietary protein concentration and degradability on response to rumen-protected methionine in lactating dairy cows ${ }^{1}$
}

\author{
G. A. Broderick, ${ }^{* 2}$ M. J. Stevenson, $\dagger^{3}$ and R. A. Patton $\ddagger$ \\ ${ }^{*}$ Agricultural Research Service, USDA, US Dairy Forage Research Center, 1925 Linden Drive West, Madison, WI 53706 \\ †Degussa Canada Inc., Burlington, Ontario, Canada L7R 3Y8 \\ ‡Nittany Dairy Nutrition Inc., Mifflinburg, PA 17844
}

\section{ABSTRACT}

An incomplete $8 \times 8$ Latin square trial (4-wk periods; 12 wk total) using 32 multiparous and 16 primiparous Holstein cows was conducted to assess the production response to crude protein $(\mathrm{CP})$, digestible rumenundegraded protein (RUP), and rumen-protected Met (RPM; fed as Mepron; Degussa Corp., Kennesaw, GA). Diets contained [dry matter (DM) basis] $21 \%$ alfalfa silage, $34 \%$ corn silage, 22 to $26 \%$ high-moisture corn, 10 to $14 \%$ soybean meal, $4 \%$ soyhulls, $2 \%$ added fat, $1.3 \%$ minerals and vitamins, and 27 to $28 \%$ neutral detergent fiber. Treatments were a $2 \times 2 \times 2$ factorial arrangement of the following main effects: 15.8 or $17.1 \%$ dietary $\mathrm{CP}$, with or without supplemental rumen-undegraded protein (RUP) from expeller soybean meal, and 0 or 9 $\mathrm{g}$ of RPM/d. None of the 2- or 3-way interactions was significant. Higher dietary CP increased DM intake 1.1 $\mathrm{kg} / \mathrm{d}$ and yield of milk $1.7 \mathrm{~kg} / \mathrm{d}, 3.5 \%$ fat-corrected milk (FCM) $2.2 \mathrm{~kg} / \mathrm{d}$, fat $0.10 \mathrm{~kg} / \mathrm{d}$, and true protein $0.05 \mathrm{~kg} / \mathrm{d}$, and improved apparent $\mathrm{N}$ balance and DM and fiber digestibility. However, milk urea $\mathrm{N}$ and estimated urinary excretion of urea- $\mathrm{N}$ and total- $\mathrm{N}$ also increased, and apparent $\mathrm{N}$ efficiency (milk-N/N-intake) fell from 33 to $30 \%$ when cows consumed higher dietary CP. Positive effects of feeding more RUP were increased feed efficiency and milk fat content plus 1.8 $\mathrm{kg} / \mathrm{d}$ greater FCM and $0.08 \mathrm{~kg} / \mathrm{d}$ greater fat, but milk protein content was lower and milk urea $\mathrm{N}$ and urinary urea excretion were elevated. Supplementation with RPM increased DM intake $0.7 \mathrm{~kg} / \mathrm{d}$ and $\mathrm{FCM}$ and fat yield by 1.4 and $0.06 \mathrm{~kg} / \mathrm{d}$, and tended to increase milk fat content and yield of milk and protein.

\footnotetext{
Received April 16, 2008.

Accepted February 3, 2009.

${ }^{1}$ Mention of any trademark or proprietary product in this paper does not constitute a guarantee or warranty of the product by the USDA or the Agricultural Research Service and does not imply its approval to the exclusion of other products that also may be suitable.

${ }^{2}$ Corresponding author: glen.broderick@ars.usda.gov

${ }^{3}$ Current address: Halchemix Canada Inc., 304 Toronto Street South, Suite 216, Uxbridge, Ontario, Canada L9P 1H3.
}

Key words: rumen-protected methionine, dietary crude protein, milk yield, nitrogen efficiency

\section{INTRODUCTION}

When cows are fed more CP than is needed to meet their requirement for metabolizable AA, the excess $\mathrm{N}$ is excreted in the urine and can contribute to environmental pollution. Supplementing diets with RUP or the limiting essential AA may permit a reduction in total dietary CP. Methionine is often first limiting for production in dairy cows fed diets based on legume forages, corn silage, corn grain, and soybean meal (Schwab et al., 1976; Pisulewski et al., 1996; NRC, 2001). Several studies have shown that supplementing these diets with rumen-protected Met (RPM) increased milk yield (Schmidt et al., 1999) as well as milk protein content (Armentano et al., 1997; Berthiaume et al., 2006) and yield (Armentano et al., 1997; Rulquin and Delaby, 1997). In one study, we observed that milk and protein yield increased when $\mathrm{CP}$ was reduced from 18.3 to $17.3 \%$ and to $16.1 \%$ when diets were also supplemented with RPM; however, further reduction of dietary $\mathrm{CP}$ to $14.8 \%$ depressed production of milk, FCM, and fat from that at $16.1 \%$ (Broderick et al., 2008).

Leonardi et al. (2003) reported that supplementing with RPM increased milk protein concentration at both 16.1 and $18.8 \%$ dietary $\mathrm{CP}$, with no interactions, suggesting that there would be a similar response in protein yield when providing the limiting AA to diets that differ in CP content. However, in the second of our 2 studies (Broderick et al., 2008), RPM did not improve production of milk or milk components when added to diets containing either 16.1 or $17.3 \% \mathrm{CP}$, perhaps because cows in that trial consumed about $10 \%$ less DM and mobilized body protein, compared with cows in the first study where RPM supplementation allowed the feeding of less CP. Reduced DM intake would reduce MP supply from both microbial synthesis and RUP; thus, differences in response will likely occur with differences in the amount of MP available to support production. 
A follow-up trial was conducted to study the effects on production and nutrient utilization of adding RPM as Mepron (Degussa Corp., Kennesaw, GA) to diets varying in MP supply due to differing levels of $\mathrm{CP}$ and RUP. Diets containing 15.8 or $17.1 \%$ CP were supplemented with soybean meal RUP and RPM to determine effects on production of milk and milk components.

\section{MATERIALS AND METHODS}

At the beginning of the trial, 32 multiparous Holstein cows (mean parity 2.6, SD 0.8), averaging (mean $\pm \mathrm{SD}$ ) $43 \pm 6 \mathrm{~kg}$ of milk/d, $128 \pm 45 \mathrm{DIM}$, and $633 \pm 46 \mathrm{~kg}$ of BW, and 16 primiparous Holstein cows, averaging $39 \pm 2 \mathrm{~kg}$ milk/d, $132 \pm 45 \mathrm{DIM}$, and $563 \pm 59 \mathrm{~kg}$ of BW, were blocked by parity and DIM and randomly assigned within squares to treatment sequences in 6 replicated, incomplete $8 \times 8$ Latin squares with 3 experimental periods. Periods lasted $28 \mathrm{~d}$ and consisted of $14 \mathrm{~d}$ for diet adaptation and $14 \mathrm{~d}$ for data and sample collection. All cows were injected with bST (500 mg of Posilac, Monsanto, St. Louis, MO) beginning on d 1 of the trial and at 14-d intervals thereafter until completion of the study. Cows were housed in tie stalls and had free access to water throughout the experiment. Care and handling of the animals was conducted as outlined by the guidelines of the University of Wisconsin institutional animal care and use committee.

Diets were fed as TMR and were formulated principally from alfalfa silage, rolled corn silage, rolled highmoisture shelled corn, solvent-extracted soybean meal, expeller soybean meal (Soyplus, West Central Coop, Ralston, IA), soyhulls, plus other ingredients. Diets were fed as a $2 \times 2 \times 2$ arrangement of treatments: 15.8 or $17.1 \%$ CP (increased by substituting part of the high-moisture shelled corn with soybean meal), supplemental protein from only solvent-extracted soybean meal or from a mixture of solvent-extracted soybean meal and expeller soybean meal, and 0 or $9 \mathrm{~g}$ of $\mathrm{RPM} / \mathrm{d}$, added to the diet as $0.062 \%$ Mepron (Degussa Corp.), assuming an intake of $24 \mathrm{~kg}$ of DM/d and an equivalence of $0.6 \mathrm{~g}$ of metabolizable Met/g of Mepron (Berthiaume et al., 2001). The TMR were prepared by blending individual feed ingredients plus a premix composed of ground shelled corn, minerals, vitamins, and Mepron; the premix was added to the TMR at $3.36 \%$ of the DM. Diets were offered once daily at 1000 $\mathrm{h}$ after orts were collected daily at $0900 \mathrm{~h}$. Amounts of feed offered were adjusted daily to allow refusals equal to 5 to $10 \%$ of intake.

Daily samples of approximately $0.5 \mathrm{~kg}$ of silages, high-moisture shelled corn, each TMR, and orts were collected, stored at $-20^{\circ} \mathrm{C}$, and used to make weekly composites. Weekly samples of the soybean meals, soyhulls, added fat source, and premix also were taken.

Dry matter contents of samples of weekly composites and individual feed samples were determined by drying at $60^{\circ} \mathrm{C}$ (forced-air oven) for $48 \mathrm{~h}$. The $60^{\circ} \mathrm{C} \mathrm{DM}$ contents of dietary ingredients were used weekly to adjust as-fed compositions of the TMR. Dry matter intake was computed based on the $60^{\circ} \mathrm{C} \mathrm{DM}$ contents of the TMR and orts. These samples were ground to pass a $1-\mathrm{mm}$ Wiley mill screen (Arthur H. Thomas, Philadelphia, PA) and analyzed later for total N (Leco FP-2000 Nitrogen Analyzer, Leco Instruments Inc., St. Joseph, MI), absolute DM, ash, and OM (AOAC, 1980), sequentially (Van Soest et al., 1991) for NDF, ADF, and ADIN using heat-stable $\alpha$-amylase and $\mathrm{Na}_{2} \mathrm{SO}_{3}$ (Hintz et al., 1995), and for neutral detergent insoluble N (NDIN) without use of $\mathrm{Na}_{2} \mathrm{SO}_{3}$ (Licitra et al., 1996). For AA determination, samples of feed were predigested with performic acid to stabilize Met and Cys, treated with hydrobromic acid to destroy the performic acid, and then acid-hydrolyzed with $6 \mathrm{~N} \mathrm{HCl}$ (method 994.12; AOAC, 1997). A separate acid hydrolysis $(6 \mathrm{~N} \mathrm{HCl})$ and digestion procedure was used for Phe, Tyr, and His because those AA are destroyed during the oxidation process and by reaction with hydrobromic acid. Concentrations of AA were quantified by ion exchange chromatography (Beckman 6300, Beckman Instruments, Palo Alto, CA). Silage extracts were prepared in distilled water from weekly composites according to Muck (1987), pH determined immediately, and extracts were analyzed for ammonia and total free AA (Broderick et al., 2004) using flow-injection (Lachat Quik-Chem 8000 FIA Lachat Instruments, Milwaukee, WI), and for NPN (Muck, 1987; VarioMax CN, Elementar Analysensystem GmbH, Hanau, Germany). Weekly TMR composites were analyzed for indigestible ADF (ADF remaining after $12 \mathrm{~d}$ of in situ incubation; Huhtanen et al., 1994). The TMR composites also were analyzed for total fat (method 920.39; AOAC, 1997; Dairyland Laboratories, Arcadia, WI), starch (Hall et al., 1999), and NDIN (Van Soest et al., 1991; Hintz et al., 1995) to compute NFC. Compositions of major feed ingredients are in Table 1 and that of diets are in Table 2.

Cows were milked twice daily at 0600 and $1700 \mathrm{~h}$, and milk yield was recorded at each milking in all experimental periods. Milk samples from a.m. and p.m. milkings were collected on d 17 and 24 of each period and analyzed for fat, true protein, lactose, and SNF by infrared analysis (AgSource, Verona, WI) with a Foss FT6000 (Foss North America Inc., Eden Prairie, MN) using AOAC (1990; method 972.16). For MUN determination, $5 \mathrm{~mL}$ of milk samples from both milkings was treated with $5 \mathrm{~mL}$ of $25 \%$ (wt/vol) TCA. Samples 
Table 1. Chemical composition of silages and principal concentrate ingredients ${ }^{1}$

\begin{tabular}{|c|c|c|c|c|c|c|}
\hline Item & AS & CS & HMSC & SSBM & ESBM & Soyhulls \\
\hline $\mathrm{CP}, \%$ of $\mathrm{DM}$ & 23.8 & 7.7 & 8.1 & 54.6 & 48.2 & 12.2 \\
\hline Ash, $\%$ of DM & 12.3 & 3.28 & 1.23 & 7.66 & 6.88 & 5.36 \\
\hline $\mathrm{ADF}, \%$ of $\mathrm{DM}$ & 27.5 & 23.1 & 2.1 & 4.6 & 7.3 & 44.8 \\
\hline Hemicellulose, \% of DM & 10.8 & 16.4 & 6.5 & 3.2 & 9.7 & 19.2 \\
\hline NDIN ${ }^{2} \%$ of total $\mathrm{N}$ & 13.2 & 19.3 & 14.6 & 7.5 & 27.6 & 11.0 \\
\hline \multicolumn{7}{|l|}{ Essential AA ( $\mathrm{g} / 100 \mathrm{~g}$ of $\mathrm{CP})$} \\
\hline Arg & 2.11 & 2.48 & 4.09 & 7.61 & 7.34 & 5.03 \\
\hline His & 1.98 & 1.89 & 2.81 & 2.76 & 2.72 & 2.47 \\
\hline Ile & 4.01 & 3.20 & 3.29 & 4.71 & 4.67 & 3.63 \\
\hline Leu & 7.12 & 8.33 & 11.35 & 8.09 & 7.85 & 6.18 \\
\hline Lys & 4.29 & 2.52 & 2.93 & 6.43 & 5.95 & 6.10 \\
\hline Ammonia, $\%$ of total $\mathrm{N}$ & 5.1 & 9.0 & - & - & - & - \\
\hline Total free AA N ${ }^{5} \%$ of total $\mathrm{N}$ & 20.8 & 23.7 & - & - & - & - \\
\hline NPN, $\%$ of total $\mathrm{N}$ & 58.4 & 64.9 & - & - & - & - \\
\hline $\mathrm{pH}$ & 4.7 & 3.6 & - & - & - & - \\
\hline
\end{tabular}

${ }^{1} \mathrm{AS}=$ alfalfa silage; $\mathrm{CS}=$ corn silage ESBM = expeller soybean meal; HMSC = high-moisture shelled corn; $\mathrm{SSBM}=$ solvent soybean meal.

${ }^{2} \mathrm{NDIN}=$ neutral detergent insoluble $\mathrm{N}$.

${ }^{3}$ Fraction B3 = NDIN (\% of total N) - ADIN (\% of total N) (Sniffen et al., 1992).

${ }^{4} \mathrm{NFC}=100-(\% \mathrm{NDF}-\mathrm{NDIN} \times 6.25)-\% \mathrm{CP}-\%$ Fat $-\%$ Ash, using tabular values for fat content of these ingredients $(\mathrm{NRC}, 2001)$.

${ }^{5}$ Total free AA N $=$ total free AA, $\mathrm{mmol} \times(40.3 \mathrm{mg}$ of $\mathrm{N} / \mathrm{mmol}$ of total free AA) (Broderick, 1987).

were vortexed and allowed to stand for $30 \mathrm{~min}$ at room temperature before filtering through Whatman no. 1 filter paper. Filtrates were stored at $-20^{\circ} \mathrm{C}$ until MUN analysis by an automated colorimetric assay (Broderick and Clayton, 1997) adapted to flow-injection (Lachat Quik-Chem 8000 FIA). Concentrations and yields of fat, true protein, lactose, and SNF, and MUN concentration were all computed as the weighted means from a.m. and p.m. milk yields on each test day. Yield of $3.5 \%$ FCM (Sklan et al., 1992) also was computed. Efficiency of conversion of feed DM was calculated for each cow over the last 2 wk of each period by dividing mean yield of actual milk and FCM by mean DM intake. Similarly, apparent efficiency of utilization of feed $\mathrm{N}$ (assuming no retention or mobilization of body $\mathrm{N}$ ) was calculated for each cow by dividing mean milk $\mathrm{N}$ output (milk true protein/6.38) by mean $\mathrm{N}$ intake. For computation of BW change, BW was measured on 3 consecutive days at the beginning of the experiment and at the end of each period.

Fecal grab samples were collected from all cows approximately $6 \mathrm{~h}$ prefeeding $(0400 \mathrm{~h})$ and $6 \mathrm{~h}$ postfeeding $(1600 \mathrm{~h})$ on d 26 or 27 of each period, transferred to aluminum pans, and held at $60^{\circ} \mathrm{C}$ in a forced-air oven until completely dry. Fecal samples then were ground to pass a 1-mm Wiley mill screen, and a single composite was prepared for each cow in each period by mixing equal DM from both samples. Fecal samples were analyzed for $\mathrm{DM}, \mathrm{OM}, \mathrm{NDF}, \mathrm{ADF}$, total N, and indigestible ADF as described earlier. Indigestible ADF was used as an internal marker to estimate apparent nutrient digestibility and fecal $\mathrm{N}$ output (Cochran et al., 1986). When fecal sampling was done, spot urine samples were obtained from all cows by mechanical stimulation of the vulva. After collection, $15 \mathrm{~mL}$ of urine was pipetted into specimen containers holding $60 \mathrm{~mL}$ of $0.072 \mathrm{~N} \mathrm{H}_{2} \mathrm{SO}_{4}$ and stored at $-20^{\circ} \mathrm{C}$ until analysis. After thawing at room temperature, urine samples were analyzed for creatinine using a picric acid assay (Oser, 1965) adapted to flow-injection analysis (Lachat QuikChem 8000 FIA), for total N (Leco FP-2000 Nitrogen Analyzer), and for urea with the colorimetric method used for MUN. Daily urine volume and excretion of urea $\mathrm{N}$ and total $\mathrm{N}$ were estimated from urinary creatinine concentration assuming a creatinine excretion rate of $29 \mathrm{mg} / \mathrm{kg}$ of BW (Valadares et al., 1999).

\section{Statistical Analysis}

The lactation trial was conducted as an incomplete $8 \times 8$ Latin square, replicated 6 times. It was intended from the outset to run the trial for 3 periods only, 
Table 2. Composition of diets A to H containing 2 levels of CP (15.8 and 17.1\%), 2 levels of expeller soybean meal (ESBM; 0 and $5 \%$ ), and 2 levels of rumen-protected $\mathrm{Met}^{1}$ (RPM; 0 and $9 \mathrm{~g} / \mathrm{d}$ )

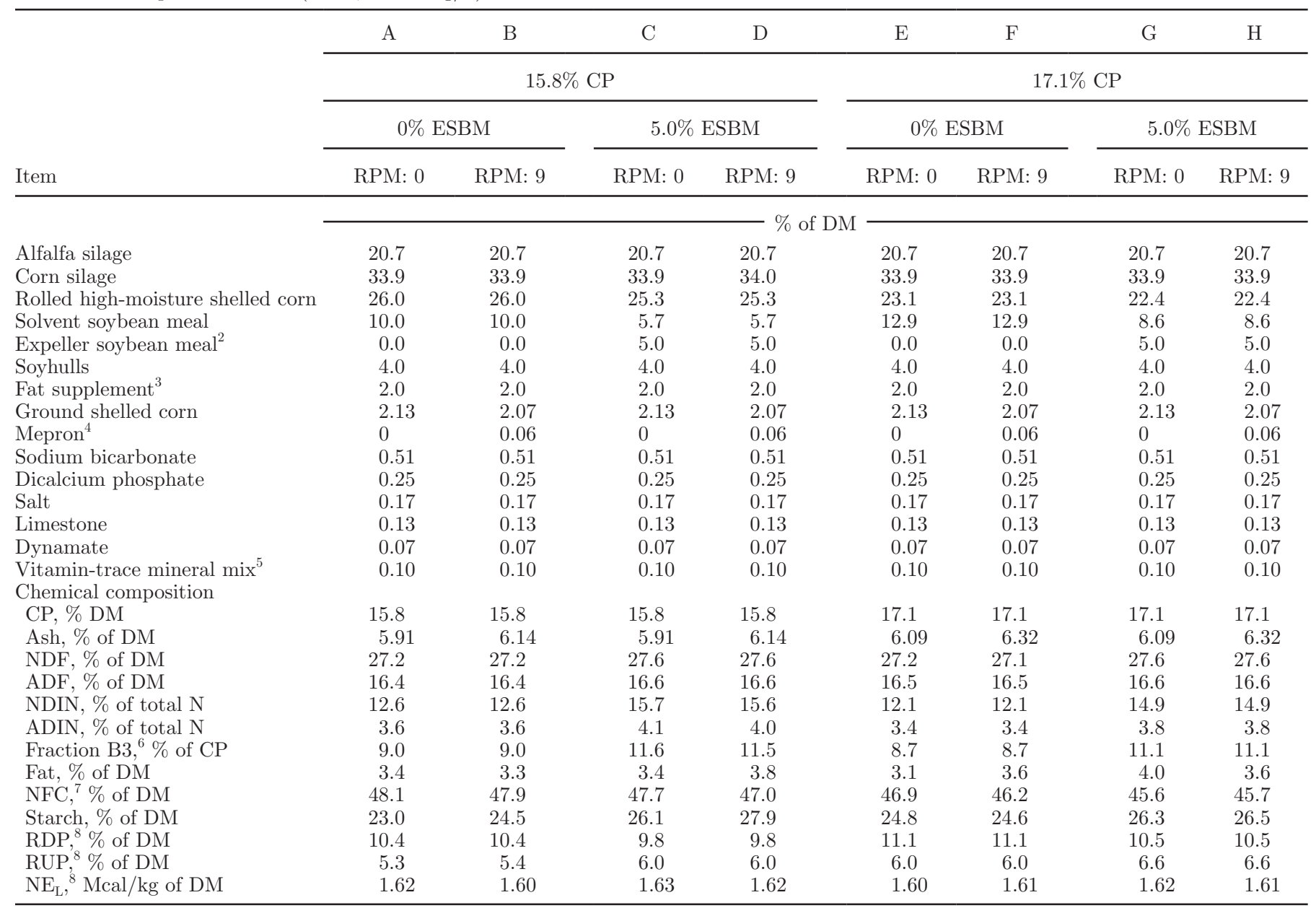

${ }^{1}$ Computed assuming $60 \%$ metabolizability of RPM in Mepron (Berthiaume et al., 2001) and $24 \mathrm{~kg} / \mathrm{d}$ of DM intake.

${ }^{2}$ SoyPlus, West Central Coop (Ralston, IA).

${ }^{3}$ Energy Booster 100, MS Specialty Nutrition (Dundee, IL).

${ }^{4}$ Rumen-protected Met product from Degussa Corp. (Kennesaw, GA).

${ }^{5}$ Provided (per $\mathrm{kg}$ of DM): $56 \mathrm{mg}$ of $\mathrm{Zn}, 46 \mathrm{mg}$ of $\mathrm{Mn}, 22 \mathrm{mg}$ of Fe, $12 \mathrm{mg}$ of Cu, $0.9 \mathrm{mg}$ of I, $0.4 \mathrm{mg}$ of Co, $0.3 \mathrm{mg}$ of Se, 6,440 IU of vitamin A, 2,000 IU of vitamin D, and 16 IU of vitamin E.

${ }^{6}$ Fraction B3 = neutral detergent insoluble N (NDIN) (\% of total N) - ADIN (\% of total N) (Sniffen et al., 1992).

${ }^{7} \mathrm{NFC}=100-(\% \mathrm{NDF}-\mathrm{NDIN} \times 6.25)-\% \mathrm{CP}-\%$ Fat $-\%$ Ash

${ }^{8}$ Estimated using the NRC (2001) model based on observed DM intakes.

rather than for a full 8 periods to avoid confounding effects due to the decline in production that would have occurred later in the lactation curve. The 8 diets were designated A through $\mathrm{H}$ (Table 2). Six incomplete 8 $\times 8$ Latin squares were constructed by fixing the first column of treatments, ordered $\mathrm{A}$ through $\mathrm{H}$, as the diets fed in period 1 , and then randomly assigning 2 of 7 possible columns of treatments (ordered B, C, ... $\mathrm{A} ; \mathrm{C}, \mathrm{D}, \ldots, \mathrm{B} ; \ldots$. $\mathrm{H}, \mathrm{A}, \ldots, \mathrm{G})$ as the subsequent series of diets in periods 2 and 3 . In this arrangement, columns represented periods and rows represented cows within squares. The 6 groups of cows were blocked as described and randomly assigned to 1 of these 6 incomplete Latin squares. Using this approach, 40 of the 56 possible changeovers from each diet to every other diet occurred twice and 16 occurred once. Mean intake and production data from the last $14 \mathrm{~d}$ of each period, and average excretion and digestibility data obtained using spot fecal and urine sampling at the end of each period were computed for each cow and analyzed as a replicated, incomplete $8 \times 8$ Latin square using the mixed model of SAS (SAS Institute, 1999-2000). The model included cow (within square), square, period, dietary CP, RUP, and RPM, 7 carryover effects, interactions 
of $\mathrm{CP} \times \mathrm{RUP}, \mathrm{CP} \times \mathrm{RPM}$, and RUP $\times \mathrm{RPM}$, as well as the 3 -way interaction $\mathrm{CP} \times \mathrm{RUP} \times \mathrm{RPM}$; all terms were considered fixed except cow (within square), which was considered random. The test for carryover effects, which was included because of the unbalanced design, was analogous to that of Haber and Lucas (http:// www4.stat.ncsu.edu/\%7Egumpertz/ggdata/carburetorexample.sas). Carryover effects in the model were limited to $7 \mathrm{df}$ and may be considered as differences from the mean carryover. Overall, interactions among main effects were not significant $(P \geq 0.09)$. Of the carryover effects, 10 out of 203 were significant $(P \leq$ $0.05) ; 8$ of these involved changeovers from diets $\mathrm{F}$ and H (17.1\% CP plus RPM, without or with RUP; Table $2)$. This indicated that carryover effects did not bias interpretation of results. To assess whether RPM addition to $15.8 \% \mathrm{CP}$ diets gave production comparable to that on $17.1 \% \mathrm{CP}$ without RPM (diets A and $\mathrm{C}$ vs. diets $\mathrm{F}$ and $\mathrm{H}$, Table 2), a mixed model similar to that used for the overall analysis without carryover effects but including "contrast" and "estimate" statements was used to determine response differences and associated 95\% confidence intervals on those diets. Interaction terms were removed from both models when $P \geq 0.25$. For all statistical analyses, significance was declared at $P \leq 0.05$ and trends at $0.05<P \leq 0.10$.

\section{RESULTS AND DISCUSSION}

Composition of the major ingredients fed in this study is in Table 1. Corn silage was similar to values in NRC (2001) tables, containing $40 \%$ NDF, $23 \%$ $\mathrm{ADF}$, and about $8 \% \mathrm{CP}$. The chemical composition of the alfalfa silage - nearly $24 \% \mathrm{CP}, 38 \% \mathrm{NDF}$ and $28 \%$ $\mathrm{ADF}$ - indicated that it was of very high quality. Both silages had in excess of $50 \%$ of total $\mathrm{N}$ as NPN, and low levels of ammonia- $\mathrm{N}$ and ADIN, indicating that they were well fermented and that $\mathrm{N}$ utilization would be expected to be normal. The high-moisture corn, solvent and expeller soybean meals, and soyhulls were also similar in composition to values reported in NRC (2001) tables. Contents of NDF and intake-adjusted $\mathrm{NE}_{\mathrm{L}}$ in the 8 diets averaged $27.4 \%$ and $1.61 \mathrm{Mcal} / \mathrm{kg}$ (Table 2), making them appropriate for high-producing dairy cows. As expected, NFC decreased from a mean of $47.7 \%$ to mean of $46.1 \%$ when $\mathrm{CP}$ was increased by substitution of high-moisture corn by soybean meal. Dietary starch levels, determined on TMR composites, ranged from 23 to $28 \%$ of DM. Although analytical results were variable, mean starch levels may be considered in the normal range for lactating cows (Oba and Allen, 2003).

Least squares means from the 8 individual treatments are reported in Table 3 . However, there were no significant interactions $(P \geq 0.09)$, so our discussion will concentrate on the main effects of dietary $\mathrm{CP}$ and supplementation with RUP and RPM. Higher dietary $\mathrm{CP}$ was associated with increased $(P \leq 0.05) \mathrm{DM}$ intake, milk content of fat and true protein, and yield of milk, 3.5\% FCM, fat, true protein, lactose, and SNF (Table 4). Kalscheur et al. (1999) found that increasing dietary $\mathrm{CP}$ increased the yields of milk, fat, and protein from wk 4 through 14 of lactation, but not after wk 19 of lactation, in high-producing dairy cows. The present findings paralleled earlier observations of greater production of milk and milk components, on diets formulated from similar feedstuffs, when CP was increased from 15.4 to $16.7 \%$ but not from 16.7 to $18.4 \%$ CP (Broderick, 2003) and from 15.7 to $16.7 \%$ but not from 16.7 to $17.7 \%$ CP (Olmos Colmenero and Broderick, 2006b). As expected, increasing dietary CP elevated apparent $\mathrm{N}$ digestibility because of greater dilution of metabolic fecal N (Schneider and Flatt, 1975). However, higher dietary $\mathrm{CP}$ also improved $(P \leq 0.05)$ apparent digestibility of $\mathrm{DM}, \mathrm{OM}, \mathrm{NDF}$, and $\mathrm{ADF}$. This suggested that RDP might have been inadequate on the lower CP diet. Although no ruminal sampling was done in the present study, ammonia $\mathrm{N}$ averaged 6.1 and $7.9 \mathrm{mg} / \mathrm{dL}$ in the rumen on a previous trial when diets contained, respectively, 16.1 and $17.3 \% \mathrm{CP}$, and total-tract digestibility of organic matter and fiber was linearly related to ruminal ammonia and dietary $\mathrm{CP}$ concentration (Broderick et al., 2008). It is not known whether improved digestibility resulted from ruminal or postruminal effects of greater dietary CP. Milk/DM intake and FCM/DM intake were not altered, suggesting that increased dietary $\mathrm{CP}$ stimulated production via greater intake and improved digestibility.

Elevated $(P<0.01)$ MUN, urinary excretion of urea $\mathrm{N}$ and total $\mathrm{N}$, urea $\mathrm{N}$ as a proportion of total urinary $\mathrm{N}$, and total manure $\mathrm{N}$ excretion, plus depressed $(P$ $<0.01) \mathrm{N}$ efficiency all indicated that utilization of the additional $\mathrm{N}$ on the higher $\mathrm{CP}$ diet was impaired (Table 4). Several studies have shown that reducing dietary CP improved apparent $\mathrm{N}$ efficiency (Wu and Satter, 2000; Broderick, 2003; Olmos Colmenero and Broderick, 2006a), but maximal $\mathrm{N}$ efficiency in another study came at the expense of depressed yield of milk and milk components (Broderick et al., 2008). Based on intakes observed in the present trial, the NRC (2001) model predicted $\mathrm{NE}_{\mathrm{L}}$-limited milk yields of 41 and 43 $\mathrm{kg} / \mathrm{d}$ but MP-limited milk yields of 38 and $43 \mathrm{~kg} / \mathrm{d}$ for diets containing, respectively, 15.8 and $17.1 \%$ CP. This suggested that supply of MP, rather than $\mathrm{NE}_{\mathrm{L}}$, limited production. Moreover, BW gain was similar at about $0.4 \mathrm{~kg} / \mathrm{d}$ across all diets. The $2 \mathrm{~kg} / \mathrm{d}$ difference for $\mathrm{NE}_{\mathrm{L}}$-limited milk was the result of the $1.1 \mathrm{~kg} / \mathrm{d}$ greater $\mathrm{DM}$ intake on $17.1 \% \mathrm{CP}$. Thus, at equal $\mathrm{NE}_{\mathrm{L}}$ intake, 
Table 3. Least squares means for production, excretion, and apparent digestibility in lactating dairy cows by dietary treatment

\begin{tabular}{|c|c|c|c|c|c|c|c|c|c|}
\hline Item & \multicolumn{4}{|c|}{$15.8 \% \mathrm{CP}$} & \multicolumn{4}{|c|}{$17.1 \% \mathrm{CP}$} & $\mathrm{SE}^{3}$ \\
\hline DM intake, $\mathrm{kg} / \mathrm{d}$ & 24.3 & 24.7 & 23.9 & 24.6 & 25.3 & 25.9 & 24.8 & 25.9 & 0.53 \\
\hline $\mathrm{N}$ intake, $\mathrm{g} / \mathrm{d}$ & 611 & 616 & 613 & 625 & 707 & 705 & 676 & 698 & 14.2 \\
\hline BW gain, kg/d & 0.38 & 0.33 & 0.26 & 0.44 & 0.35 & 0.40 & 0.52 & 0.50 & 0.155 \\
\hline $3.5 \%$ FCM, kg/d & 39.7 & 38.2 & 40.2 & 44.2 & 42.0 & 43.1 & 41.9 & 44.2 & 1.20 \\
\hline FCM/DM intake & 1.64 & 1.55 & 1.69 & 1.80 & 1.67 & 1.67 & 1.69 & 1.71 & 0.041 \\
\hline Milk fat, $\%$ & 3.45 & 3.45 & 3.57 & 3.81 & 3.65 & 3.68 & 3.64 & 3.79 & 0.113 \\
\hline Milk fat, $\mathrm{kg} / \mathrm{d}$ & 1.38 & 1.33 & 1.42 & 1.60 & 1.50 & 1.54 & 1.49 & 1.59 & 0.055 \\
\hline Milk true protein, $\%$ & 3.22 & 3.25 & 3.13 & 3.16 & 3.19 & 3.29 & 3.17 & 3.17 & 0.050 \\
\hline Milk true protein, $\mathrm{kg} / \mathrm{d}$ & 1.29 & 1.24 & 1.24 & 1.34 & 1.30 & 1.36 & 1.31 & 1.34 & 0.032 \\
\hline Milk lactose, \% & 4.85 & 4.74 & 4.83 & 4.77 & 4.82 & 4.83 & 4.74 & 4.83 & 0.052 \\
\hline \multicolumn{3}{|l|}{ Excretion $^{4}$} & 25.7 & 19.9 & 20.7 & 20.4 & 23.2 & 24.0 & 1.85 \\
\hline Urine urea-N, $\mathrm{g} / \mathrm{d}$ & 123 & 130 & 131 & 137 & 173 & 173 & 181 & 180 & 5.5 \\
\hline Total urine-N, g/d & 178 & 175 & 180 & 176 & 204 & 217 & 214 & 220 & 7.2 \\
\hline Urea-N/Total urine-N, \% & 72.9 & 74.8 & 75.2 & 77.4 & 86.3 & 79.7 & 85.2 & 83.9 & 2.77 \\
\hline Fecal DM, kg/d & 8.8 & 9.6 & 9.1 & 9.8 & 9.1 & 10.1 & 9.5 & 8.7 & 0.34 \\
\hline Fecal N, g/d & 236 & 245 & 251 & 266 & 246 & 283 & 269 & 240 & 10.8 \\
\hline Manure-N,g/d & 411 & 420 & 432 & 442 & 450 & 501 & 484 & 461 & 14.6 \\
\hline N-balance, ${ }^{5} \mathrm{~g} / \mathrm{d}$ & 1 & -4 & -4 & -30 & 49 & -24 & 3 & 30 & 11.8 \\
\hline \multicolumn{10}{|l|}{ Apparent digestibility ${ }^{6}$} \\
\hline $\mathrm{DM}, \%$ & 64.0 & 61.0 & 62.0 & 59.9 & 63.9 & 60.5 & 61.9 & 66.3 & 0.94 \\
\hline $\mathrm{OM}, \%$ & 65.1 & 62.1 & 63.3 & 61.1 & 65.2 & 62.3 & 63.4 & 67.5 & 0.94 \\
\hline NDF, \% & 39.1 & 33.5 & 37.1 & 34.9 & 38.1 & 34.4 & 38.4 & 42.7 & 1.40 \\
\hline $\mathrm{ADF}, \%$ & 40.6 & 35.1 & 37.5 & 36.2 & 40.5 & 36.7 & 40.0 & 43.7 & 1.38 \\
\hline
\end{tabular}

${ }^{1}$ Dietary content of expeller soybean meal, the source of supplemental RUP.

${ }^{2}$ Computed assuming $60 \%$ metabolizability of rumen-protected Met (RPM) in Mepron (Berthiaume et al., 2001) and 24 kg/d of DM intake; Mepron from Degussa Corp. (Kennesaw, GA).

${ }^{3}$ Standard error of the least squares means.

${ }^{4}$ Urinary excretion estimated using creatinine as a volume marker and fecal excretion estimated using indigestible ADF as an internal marker.

${ }^{5}$ Nitrogen balance computed assuming milk true protein contains $6.38 \% \mathrm{~N}$.

${ }^{6}$ Apparent digestibilities estimated from spot fecal sampling, using indigestible ADF as an internal marker.

MP-limited milk yield should have been $3 \mathrm{~kg} / \mathrm{d}$ lower (equivalent to $90 \mathrm{~g} / \mathrm{d}$ of protein at $3 \%$ milk protein content) on diets containing $15.8 \% \mathrm{CP}$. Yield on diets containing $17.1 \% \mathrm{CP}$ was only greater by $1.7 \mathrm{~kg} / \mathrm{d}$ of milk and $50 \mathrm{~g} / \mathrm{d}$ of protein.

The positive effects of feeding more RUP as expeller soybean meal (Table 4$)$ were improved $(P=0.01)$ feed efficiency, higher $(P=0.03)$ milk fat content, and greater $(P \leq 0.02)$ yield of FCM and fat. Greater apparent NDF digestibility $(P=0.04)$ was also observed. Heat processing of soybean meal results in formation of protein-bound NDF; NDF-bound CP in feedstuffs often remains digestible in the rumen (Haugen et al., 2006) and total tract (Aldrich et al., 1995). Although milk true protein yield was not altered, RUP supplementa- tion elevated MUN $(P<0.01)$ and urinary excretion of urea $\mathrm{N}(P=0.01)$ and reduced milk protein content $(P=0.01)$. This suggested that the low Met content in soybean meal RUP limited its utilization.

Supplementing with RPM increased $(P \leq 0.05)$ feed intake and yield of FCM and fat and gave trends for increased milk fat content and yield of milk and milk true protein (Table 4). Although several studies found greater fat yield with increased Met supply (Munneke et al., 1991; Overton et al., 1996), others reported no effect on this trait (Yang et al., 1986; Pisulewski et al., 1996). Overton et al. (1998) observed contradictory responses with RPM: increased fat yield on a diet high in ground shelled corn but decreased fat secretion on a higher NDF diet containing corn gluten feed. We found 
Table 4. Effect of dietary CP content and supplementation of RUP as expeller soybean meal and rumen-protected Met (RPM) on production, excretion, and apparent digestibility in lactating dairy cows

\begin{tabular}{|c|c|c|c|c|c|c|c|c|c|c|}
\hline \multirow[b]{2}{*}{ Item } & \multicolumn{3}{|c|}{$\mathrm{CP}, \%$ of $\mathrm{DM}$} & \multicolumn{3}{|c|}{ RUP, ${ }^{1} \%$ of DM } & \multicolumn{3}{|c|}{$\mathrm{RPM},{ }^{2} \mathrm{~g} / \mathrm{d}$} & \multirow[b]{2}{*}{$\mathrm{SE}^{3}$} \\
\hline & 15.8 & 17.1 & $P>\mathrm{F}^{4}$ & 0 & 5 & $P>\mathrm{F}$ & 0 & 9 & $P>\mathrm{F}$ & \\
\hline $\mathrm{N}$ intake, $\mathrm{g} / \mathrm{d}$ & 616 & 696 & $<0.01$ & 660 & 653 & 0.46 & 652 & 661 & 0.31 & 9.7 \\
\hline BW gain, kg/d & 0.35 & 0.45 & 0.40 & 0.37 & 0.43 & 0.58 & 0.38 & 0.42 & 0.71 & 0.077 \\
\hline Milk yield, kg/d & 40.0 & 41.7 & $<0.01$ & 40.5 & 41.3 & 0.24 & 40.4 & 41.4 & 0.10 & 0.72 \\
\hline Milk/DM intake & 1.65 & 1.65 & 0.90 & 1.62 & 1.68 & $<0.01$ & 1.65 & 1.65 & 0.93 & 0.026 \\
\hline Milk fat, $\%$ & 3.57 & 3.69 & 0.05 & 3.56 & 3.70 & 0.03 & 3.58 & 3.68 & 0.10 & 0.086 \\
\hline Milk fat, $\mathrm{kg} / \mathrm{d}$ & 1.43 & 1.53 & $<0.01$ & 1.44 & 1.52 & 0.01 & 1.45 & 1.51 & 0.04 & 0.039 \\
\hline Milk true protein, \% & 3.19 & 3.20 & 0.63 & 3.24 & 3.16 & 0.01 & 3.18 & 3.22 & 0.16 & 0.035 \\
\hline Milk true protein, $\mathrm{kg} / \mathrm{d}$ & 1.28 & 1.33 & 0.01 & 1.30 & 1.31 & 0.69 & 1.28 & 1.32 & 0.09 & 0.020 \\
\hline Milk lactose, $\%$ & 4.80 & 4.81 & 0.83 & 4.81 & 4.79 & 0.64 & 4.81 & 4.79 & 0.62 & 0.033 \\
\hline Milk lactose, $\mathrm{kg} / \mathrm{d}$ & 1.93 & 2.00 & 0.05 & 1.94 & 1.98 & 0.31 & 1.95 & 1.98 & 0.41 & 0.036 \\
\hline Milk SNF, \% & 8.88 & 8.92 & 0.48 & 8.93 & 8.86 & 0.24 & 8.88 & 8.91 & 0.59 & 0.058 \\
\hline Urine urea-N, g/d & 130 & 176 & $<0.01$ & 150 & 157 & 0.05 & 152 & 155 & 0.40 & 3.4 \\
\hline Total urine-N, g/d & 177 & 214 & $<0.01$ & 194 & 198 & 0.40 & 194 & 197 & 0.52 & 4.0 \\
\hline Urea-N/total urine-N, \% & 75.1 & 83.8 & $<0.01$ & 78.4 & 80.4 & 0.31 & 79.9 & 78.9 & 0.63 & 1.40 \\
\hline Fecal DM, kg/d & 9.4 & 9.4 & 1.00 & 9.4 & 9.3 & 0.64 & 9.1 & 9.6 & 0.06 & 0.20 \\
\hline Fecal N, g/d & 249 & 259 & 0.13 & 252 & 256 & 0.59 & 250 & 258 & 0.26 & 6.5 \\
\hline Manure-N, g/d & 426 & 474 & $<0.01$ & 445 & 455 & 0.37 & 444 & 456 & 0.24 & 8.7 \\
\hline N-balance, ${ }^{6} \mathrm{~g} / \mathrm{d}$ & -9.4 & 14.8 & $<0.01$ & 5.7 & -0.2 & 0.49 & 12.2 & -6.7 & 0.03 & 5.96 \\
\hline \multicolumn{11}{|l|}{ Apparent digestibility $^{7}$} \\
\hline $\mathrm{DM}, \%$ & 61.7 & 63.1 & 0.03 & 62.4 & 62.5 & 0.81 & 63.0 & 61.9 & 0.11 & 0.52 \\
\hline OM, \% & 62.9 & 64.6 & 0.01 & 63.7 & 63.8 & 0.83 & 64.2 & 63.2 & 0.13 & 0.52 \\
\hline NDF, $\%$ & 36.2 & 38.4 & 0.02 & 36.3 & 38.3 & 0.05 & 38.2 & 36.4 & 0.07 & 0.74 \\
\hline $\mathrm{ADF}, \%$ & 37.4 & 40.2 & $<0.01$ & 38.2 & 39.4 & 0.25 & 39.7 & 37.9 & 0.08 & 0.75 \\
\hline $\mathrm{N}, \%$ & 59.7 & 62.7 & $<0.01$ & 61.6 & 60.8 & 0.38 & 61.7 & 60.7 & 0.23 & 0.71 \\
\hline
\end{tabular}

${ }^{1}$ Dietary content of expeller soybean meal, the source of supplemental RUP.

${ }^{2}$ Computed assuming 60\% metabolizability of RPM in Mepron (Berthiaume et al., 2001) and $24 \mathrm{~kg} / \mathrm{d}$ of DM intake; Mepron from Degussa Corp. (Kennesaw, GA).

${ }^{3}$ Standard error of the least squares means.

${ }^{4}$ Probability of the effects of dietary CP content or supplementation with RUP and RPM from Mepron.

${ }^{5}$ Urinary excretion estimated using creatinine as a volume marker and fecal excretion estimated using indigestible ADF as an internal marker.

${ }^{6} \mathrm{Nitrogen}$ balance computed assuming milk true protein contains $6.38 \% \mathrm{~N}$.

${ }^{7}$ Apparent digestibilities estimated from spot fecal sampling, using indigestible ADF as an internal marker.

that RPM supplementation improved production of fat and FCM in 1 of 2 previous trials (Broderick et al., 2008). Feeding RPM has also been shown to increase milk concentrations of total protein (Armentano et al., 1997; Berthiaume et al., 2006), true protein (Berthiaume et al., 2006; Broderick et al., 2008), and casein (Overton et al., 1998), and yields of milk (Schmidt et al., 1999), total protein (Armentano et al., 1997), and true protein (Rulquin and Delaby, 1997).

We were interested in whether RPM supplementation would allow similar production at lower dietary $\mathrm{CP}$ and, thus, reduce $\mathrm{N}$ excretion. An analysis of results obtained feeding $15.8 \% \mathrm{CP}$ plus RPM versus $17.1 \% \mathrm{CP}$ without RPM is in Table 5. This comparison suggested that DM intake and yield of milk and milk components were not different $(P \geq 0.16)$ on diets containing $15.8 \%$ $\mathrm{CP}$ plus RPM than on diets containing $17.1 \% \mathrm{CP}$ minus RPM. Also, there was substantially reduced $(P<$ 0.01) MUN, urinary excretion of urea $\mathrm{N}$ and total $\mathrm{N}$, and proportion of urea in total urinary $\mathrm{N}$, plus more than a 3 -percentage-unit improvement $(P<0.01)$ in apparent $\mathrm{N}$ efficiency. The only exception noted was that estimated N-balance (computed using true rather than total protein secretion) as well as our relatively low apparent $\mathrm{N}$ digestibilities (Table 4 ) were $44 \mathrm{~g} / \mathrm{d}$ more negative $(P<0.01)$, suggesting that $\mathrm{N}$ may have been mobilized from the tissues on the $15.8 \% \mathrm{CP}$ diets supplemented with RPM.

Flows of MP and digested (metabolizable) Lys and Met, computed using the NRC (2001) model, were esti- 
Table 5. Production and excretion results in lactating dairy cows fed $15.8 \%$ dietary CP plus supplemental rumen-protected Met (RPM; 9 g/d) versus $17.1 \%$ dietary $\mathrm{CP}$ without RPM $(0 \mathrm{~g} / \mathrm{d})$

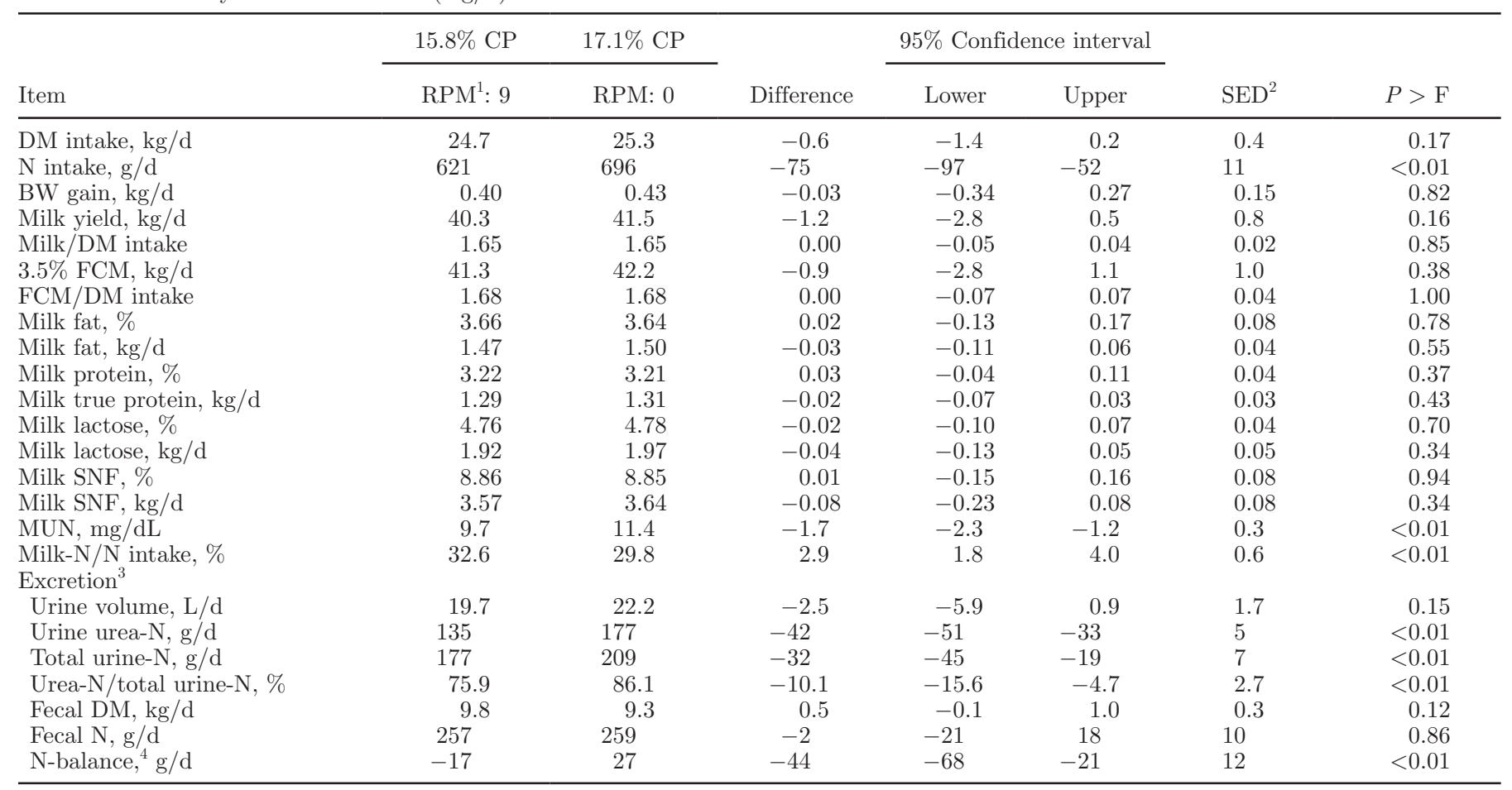

${ }^{1}$ Rumen-protected Met computed assuming 60\% metabolizability of RPM in Mepron (Berthiaume et al., 2001) and 24 kg/d of DM intake; Mepron from Degussa Corp. (Kennesaw, GA).

${ }^{2}$ Standard error of the difference.

${ }^{3}$ Urinary excretion estimated using creatinine as a volume marker and fecal excretion estimated using indigestible ADF as an internal marker.

${ }^{4}$ Nitrogen balance computed assuming milk true protein contains $6.38 \% \mathrm{~N}$.

mated to be, respectively, 276, 16 , and $4 \mathrm{~g} / \mathrm{d}$ greater on 17.1 versus $15.8 \%$ dietary $\mathrm{CP}$ (Table 6). Mean protein yield accounted for only $41 \mathrm{~g} / \mathrm{d}$ of the extra MP, a $15 \%$ rather than $67 \%$ recovery (NRC, 2001), possibly indicating that an essential AA rather than total protein limited protein secretion. Kalscheur et al. (2006) recovered $19 \%$ of supplemental $\mathrm{CP}$, added to the diet as RDP and RUP from soybean meal, as secreted milk protein. Assuming 2.7\% Met and 1.3\% Cys in milk true protein (NRC, 1982), we computed a recovery of RPM in milk Met equal to $11 \%$ and a recovery of RPM-S in milk Met and Cys of $18 \%$.

Pisulewski et al. (1996) observed a linear response in secretion of milk true protein when infusing Met abomasally to provide up to an estimated $2.4 \%$ of protein truly digested in the intestine, in supplement of Lys at $7.3 \%$ of protein truly digested in the intestine. The NRC (2001) used breakpoint analyses to estimate Met and Lys requirements for maximal milk protein concentration and yield of, respectively, about 2.4 and $7.2 \%$ of MP. These concentrations in the MP may be used to compute the proportions of "requirements" for these 2 essential AA that were met by diets fed in this study (Table 6). The Lys supply computed using the NRC
(2001) model ranged from 89 to $91 \%$ of estimated requirement; Met supply averaged $75 \%$ of this requirement without RPM and $87 \%$ with RPM addition. Feeding RPM also gave comparable improvement in Met status at both protein levels: RPM supplementation increased Met supply from 76 to $87 \%$ of estimated requirement at $15.8 \% \mathrm{CP}$ and from 74 to $86 \%$ of estimated requirement at $17.1 \%$ CP. This may explain why comparable responses to RPM have been observed at differing concentrations of dietary protein (Leonardi et al., 2003). The RPM-supplemented diets, with estimated Lys:Met ratios of about 3.1, may have had a more favorable AA pattern than the diets without RPM, with estimated Lys: Met ratio of about 3.6 (Table 6). These computations support the argument that Met supply limited production in this experiment.

\section{CONCLUSIONS}

A feeding study was conducted to assess the effects of supplementing with RPM in cows fed diets based on alfalfa and corn silages plus high moisture corn, and with $\mathrm{CP}$ and RUP varied by addition of soybean meal. Increasing dietary CP from 15.8 to $17.1 \%$ improved yield 
Table 6. Estimated supply of MP and digested (metabolizable) AA on diets containing 15.8 or $17.1 \%$ CP that were supplemented with RUP as expeller soybean meal and rumen-protected Met (RPM)

\begin{tabular}{|c|c|c|c|c|c|c|}
\hline \multirow[b]{2}{*}{ Item } & \multicolumn{2}{|c|}{$\mathrm{CP}, \%$ of $\mathrm{DM}$} & \multicolumn{2}{|c|}{ RUP, ${ }^{1} \%$ of DM } & \multicolumn{2}{|c|}{$\mathrm{RPM},{ }^{2} \mathrm{~g} / \mathrm{d}$} \\
\hline & 15.8 & 17.1 & 0 & 5.0 & 0 & 9 \\
\hline $\mathrm{MP}, \mathrm{g} / \mathrm{d}$ & 2,594 & 2,870 & 2,690 & 2,773 & 2,696 & 2,768 \\
\hline Digested Lys, g/d & 169 & 185 & 175 & 179 & 175 & 179 \\
\hline Digested Met, g/d & 51 & 55 & 53 & 53 & 49 & 58 \\
\hline Lys/Met ratio & 3.3 & 3.4 & 3.3 & 3.4 & 3.6 & 3.1 \\
\hline \multicolumn{7}{|l|}{ Estimated requirement $^{4}$} \\
\hline Lys requirement, g/d & 187 & 207 & 194 & 199 & 194 & 199 \\
\hline Met requirement, $\mathrm{g} / \mathrm{d}$ & 63 & 69 & 65 & 67 & 65 & 67 \\
\hline Lys supply, $\%$ of requirement & 90 & 90 & 91 & 89 & 90 & 90 \\
\hline Met supply, $\%$ of requirement & 82 & 80 & 82 & 79 & 75 & 87 \\
\hline
\end{tabular}

${ }^{1}$ Dietary content of expeller soybean meal, the source of supplemental RUP.

${ }^{2}$ Rumen-protected Met computed assuming 60\% metabolizability of RPM in Mepron (Berthiaume et al., 2001) and $24 \mathrm{~kg} / \mathrm{d}$ of DM intake; Mepron from Degussa Corp. (Kennesaw, GA).

${ }^{3}$ Metabolizable protein and digested (metabolizable) Met and Lys estimated using the NRC (2001) model based on observed DM intakes.

${ }^{4}$ Computed assuming digested (absorbed) Lys and Met required at, respectively, 7.2 and $2.4 \%$ of MP.

of milk and milk components, primarily via increased intake and digestibility, but also elevated urinary $\mathrm{N}$ excretion and depressed apparent N efficiency. Feeding additional RUP as expeller soybean meal improved feed efficiency and fat yield but did not alter $\mathrm{N}$ utilization, possibly because of inadequate supply of Met in this source of RUP. Adding RPM to the diet increased yield of FCM and fat, and tended to increase yield of true protein.

\section{ACKNOWLEDGMENTS}

The authors thank Rick Walgenbach and his farm crew for harvesting and storing the feedstuffs used in these trials; Jill Davidson and her barn crew for feeding and animal care at the US Dairy Forage Center Research Farm (Prairie du Sac, WI); Wendy Radloff, Mary Becker, and Steven Diederich (US Dairy Forage Research Center, Madison, WI) for assisting with sampling and laboratory analyses; Winfried Heimbeck (Evonik Degussa GmbH, Hanau, Germany) for AA analyses; and Peter Crump (University of Wisconsin, Madison) for assisting with statistical analyses, particularly the assessment of possible treatment carryover effects. Partial financial support for this research from Degussa Co. (Kennesaw, GA) is also gratefully acknowledged.

\section{REFERENCES}

Aldrich, C. G., N. R. Merchen, and J. K. Drackley. 1995. The effect of roasting temperature applied to whole soybeans on site of digestion by steers: I. Organic matter, energy, fiber, and fatty acid digestion. J. Anim. Sci. 73:2120-2130.
AOAC. 1980. Official Methods of Analysis. 13th ed. Assoc. Off. Anal. Chem., Washington, DC.

AOAC. 1990. Official Methods of Analysis. 15th ed. Assoc. Off. Anal. Chem., Arlington, VA.

AOAC. 1997. Official Methods of Analysis. 16th ed. Assoc. Off. Anal. Chem., Arlington, VA.

Armentano, L. E., S. J. Bertics, and G. A. Ducharme. 1997. Response of lactating cows to methionine or methionine plus lysine added to high protein diets based on alfalfa and heated soybeans. J. Dairy Sci. 80:1194-1199.

Berthiaume, R., P. Dubreuil, M. Stevenson, B. W. McBride, and H. Lapierre. 2001. Intestinal disappearance and mesenteric and portal appearance of amino acids in dairy cows fed ruminally protected methionine. J. Dairy Sci. 84:194-203.

Berthiaume, R., M. C. Thivierge, R. A. Patton, P. Dubreuil, M. Stevenson, B. W. McBride, and H. Lapierre. 2006. Effect of ruminally protected methionine on splanchnic metabolism of amino acids in lactating dairy cows. J. Dairy Sci. 89:1621-1634.

Broderick, G. A. 1987. Determination of protein degradation rates using a rumen in-vitro system containing inhibitors of microbial nitrogen metabolism. Br. J. Nutr. 58:463-476.

Broderick, G. A. 2003. Effects of varying dietary protein and energy levels on the production of lactating dairy cows. J. Dairy Sci. $86: 1370-1381$.

Broderick, G. A., and M. K. Clayton. 1997. A statistical evaluation of animal and nutritional factors influencing concentrations of milk urea nitrogen. J. Dairy Sci. 80:2964-2971.

Broderick, G. A., M. J. Stevenson, R. A. Patton, N. E. Lobos, and J. J. Olmos Colmenero. 2008. Effect of supplementing rumen-protected methionine on production and nitrogen excretion in lactating dairy cows. J. Dairy Sci. 91:1092-1102.

Broderick, G. A., P. Udén, M. L. Murphy, and A. Lapins. 2004. Sources of variation in rates of in vitro ruminal protein degradation. J. Dairy Sci. 87:1345-1359.

Cochran, R. C., D. C. Adams, J. D. Wallace, and M. L. Galyean. 1986. Predicting digestibility of different diets with internal markers: Evaluation of four potential markers. J. Anim. Sci. 63:14761487.

Hall, M. B., W. H. Hoover, J. P. Jennings, and T. K. M. Webster. 1999. A method for partitioning neutral detergent-soluble carbohydrates. J. Sci. Food Agric. 79:2079-2086.

Haugen, H. L., M. J. Lamothe, T. J. Klopfenstein, D. C. Adams, and M. D. Ullerich. 2006. Estimation of undegradable intake protein 
in forages using neutral detergent insoluble nitrogen at a single in situ incubation time point. J. Anim. Sci. 84:651-659.

Hintz, R. W., D. R. Mertens, and K. A. Albrecht. 1995. Effects of sodium sulfite on recovery and composition of detergent fiber and lignin. J. AOAC 78:16-22.

Huhtanen, P., K. Kaustell, and S. Jaakkola. 1994. The use of internal markers to predict total digestibility and duodenal flow of nutrients in cattle given six different diets. Anim. Feed Sci. Technol. 48:211-227.

Kalscheur, K. F., R. L. Baldwin VI, B. P. Glenn, and R. A. Kohn. 2006. Milk production of dairy cows fed differing concentrations of rumen-degraded protein. J. Dairy Sci. 89:249-259.

Kalscheur, K. F., J. H. Vandersall, R. A. Erdman, R. A. Kohn, and E. Russek-Cohen. 1999. Effects of dietary crude protein concentration and degradability on milk production responses of early, mid, and late lactation dairy cows. J. Dairy Sci. 82:545-554.

Leonardi, C., M. Stevenson, and L. E. Armentano. 2003. Effect of two levels of crude protein and methionine supplementation on performance of dairy cows. J. Dairy Sci. 86:4033-4042.

Licitra, G., T. M. Hernandez, and P. J. Van Soest. 1996. Standardization of procedures for nitrogen fractionation of ruminant feeds. Anim. Feed Sci. Technol. 57:347-358.

Muck, R. E. 1987. Dry matter level effects on alfalfa silage quality. 1. Nitrogen transformations. Trans. ASAE 30:7-14.

Munneke, R. L., D. J. Schingoethe, and D. P. Casper. 1991. Lactational evaluation of ruminally protected methionine in diets containing extruded soybeans and urea. J. Dairy Sci. 74:227-233.

NRC. 1982. United States-Canadian tables of feed composition. 3rd rev. National Academy Press, Washington, DC.

NRC. 2001. Nutrient Requirements of Dairy Cattle. 7th rev. ed. Natl. Acad. Sci., Washington, DC.

Oba, M., and M. S. Allen. 2003. Effects of diet fermentability on efficiency of microbial nitrogen production in lactating dairy cows. J. Dairy Sci. 86:195-207.

Olmos Colmenero, J. J., and G. A. Broderick. 2006a. Effect of amount and ruminal degradability of soybean meal protein on performance of lactating dairy cows. J. Dairy Sci. 89:1635-1643.

Olmos Colmenero, J. J., and G. A. Broderick. 2006b. Effect of dietary crude protein concentration on milk production and nitrogen utilization in lactating dairy cows. J. Dairy Sci. 89:1704-1712.

Oser, B. L. 1965. Hawk's Physiological Chemistry. 14 ed. McGrawHill, New York, NY.
Overton, T. R., L. S. Emmert, and J. H. Clark. 1998. Effects of source of carbohydrate and protein and rumen-protected methionine on performance of cows. J. Dairy Sci. 81:221-228.

Overton, T. R., D. W. Lacount, T. M. Cicela, and J. H. Clark. 1996. Evaluation of a ruminally protected methionine product for lactating dairy cows. J. Dairy Sci. 79:631-638.

Pisulewski, P. M., H. Rulquin, J. L. Peyraud, and R. Verite. 1996 Lactational and systemic responses of dairy cows to postruminal infusions of increasing amounts of methionine. J. Dairy Sci. 79:1781-1791.

Rulquin, H., and L. Delaby. 1997. Effects of the energy balance of dairy cows on lactational responses to rumen-protected methionine. J. Dairy Sci. 80:2513-2522.

SAS Institute. 1999-2000. SAS/STAT User's Guide. Release 8.1. SAS Institute Inc., Cary, NC.

Schmidt, J., P. Sipocz, E. Cenkvari, and J. Sipocz. 1999. Use of protected methionine (Mepron M 85) in cattle. Acta Vet. Hung. 47:409-418.

Schneider, B. H., and W. P. Flatt. 1975. The evaluation of feeds through digestibility experiments. Univ. Georgia Press, Athens.

Schwab, C. G., L. D. Satter, and A. B. Clay. 1976. Responses of lactating dairy cows to abomasal infusions of amino acids. J. Dairy Sci. 59:1254-1270.

Sklan, D., R. Ashkenazi, A. Braun, A. Devorn, and K. Taboris. 1992. Fatty acids, calcium soaps of fatty acids, and cottonseeds fed to high yielding cows. J. Dairy Sci. 75:2463-2472.

Sniffen, C. J., J. D. O'Connor, P. J. Van Soest, D. G. Fox, and J. B. Russell. 1992. A net carbohydrate and protein system for evaluating cattle diets. 2. Carbohydrate and protein availability. J. Anim. Sci. 70:3562-3577.

Valadares, R. F. D., G. A. Broderick, S. C. Valadares Filho, and M. K. Clayton. 1999. Effect of replacing alfalfa silage with high moisture corn on ruminal protein synthesis estimated from excretion of total purine derivatives. J. Dairy Sci. 82:2686-2696.

Van Soest, P. J., J. B. Robertson, and B. A. Lewis. 1991. Methods for dietary fiber, neutral detergent fiber and nonstarch polysacharides in relation to animal nutrition. J. Dairy Sci. 74:3583-3597.

Wu, Z., and L. D. Satter. 2000. Milk production during the complete lactation of dairy cows fed diets containing different amounts of protein. J. Dairy Sci. 83:1042-1051.

Yang, C. M. J., D. J. Schingoethe, and D. P. Casper. 1986. Protected methionine and heat-treated soybean meal for high producing dairy cows. J. Dairy Sci. 69:2348-2357. 